\title{
Cryptic Diversity in the Neotropical Gecko Genus Phyllopezus Peters, 1878 (Reptilia: Squamata: Phyllodactylidae): A New Species from Paraguay
}

\author{
Pier Cacciali $\mathbb{D}^{1,2,3}$ Sebastian Lotzkat, ${ }^{1}$ Tony Gamble, ${ }^{4,5}$ and Gunther Köhler ${ }^{1,2}$ \\ ${ }^{1}$ Senckenberg Forschungsinstitut und Naturmuseum Frankfurt, Senckenberganlage 25, 60325 Frankfurt a.M., Germany \\ ${ }^{2}$ Johann Wolfgang Goethe University, Institute for Ecology, Evolution \& Diversity, Biologicum, Building C, Max-von-Laue-Straße 13, \\ 60438 Frankfurt am Main, Germany \\ ${ }^{3}$ Instituto de Investigación Biológica del Paraguay, Del Escudo 1607, 1425 Asunción, Paraguay \\ ${ }^{4}$ Department of Biological Sciences, Marquette University, Milwaukee, WI 53201, USA \\ ${ }^{5}$ Bell Museum of Natural History, University of Minnesota, St. Paul, MN 55108, USA
}

Correspondence should be addressed to Pier Cacciali; pier_cacciali@yahoo.com

Received 28 January 2018; Accepted 6 June 2018; Published 16 July 2018

Academic Editor: Hynek Burda

Copyright ( 2018 Pier Cacciali et al. This is an open access article distributed under the Creative Commons Attribution License, which permits unrestricted use, distribution, and reproduction in any medium, provided the original work is properly cited.

The gecko genus Phyllopezus is distributed mainly along South America's "Dry Diagonal” (Caatinga, Cerrado, and Chaco). The genus has been the subject of recent taxonomic analyses and includes four described species and seven candidate species referred to here as Phyllopezus pollicaris sensu lato. In Paraguay, Phyllopezus is known from the Chaco and Cerrado where it is abundant, and also from a small isolated population from a rocky hill formation named "Cordillera de Los Altos" (Los Altos mountain range). Here we analyzed genetic samples from across its range, including new samples from Paraguay, using DNA barcoding analysis of the mitochondrial 16S gene and phylogenetic analyses using both Bayesian and Maximum Likelihood methods. We found genetic and morphological differences among geckos from the Los Altos mountain range and the remaining Phyllopezus populations. Using both molecular and morphological evidence we describe a new Phyllopezus species, sister to P. przewalskii. Genetic differentiation among described and putative Phyllopezus species is greater than their morphological differences, which likely accounts for these cryptic taxa remaining undescribed for so long.

\section{Introduction}

In South America, the so-called "Dry Diagonal" of dry seasonal woodland formations stretches from eastern Brazil to northern Argentina and includes the Caatinga, Cerrado, and Chaco ecoregions. The origin of these biomes and the evolution of their faunas have evoked much interest during the past decades [1-4] and are still a significant topic for understanding the evolution of the Neotropical biota [5-8]. As important as these "Dry Diagonal" ecoregions are, they remain poorly known with new species being described at an increasing rate [9-11]. Molecular data are now often used for species identification [12-14] and species delimitation [1518] helping taxonomists to improve the global knowledge of alpha taxonomy. This led to the recognition of many cryptic phylogenetic lineages of reptiles in the Neotropics $[9,19]$. A good example of this undescribed diversity involves lizards of the genus Phyllopezus distributed mainly along the "Dry Diagonal" $[10,11]$.

Phyllopezus is a genus of Neotropical geckos, which for decades was considered as monotypic with two subspecies: P. pollicaris pollicaris (Spix, 1825) and P. p. przewalskii Koslowsky, 1895 [20, 21]. Later, P. periosus Rodrigues, 1986 was described from northeastern Brazil [22], and more recently P. maranjonensis Koch, Venegas \& Böhme, 2006 from Peru [23]. Furthermore, a detailed phylogenetic study, based on a multilocus genetic approach, showed a deep phylogenetic nesting of Bogertia lutzae within Phyllopezus and accordingly placed that species in the genus Phyllopezus to reestablish monophyly [10]. 


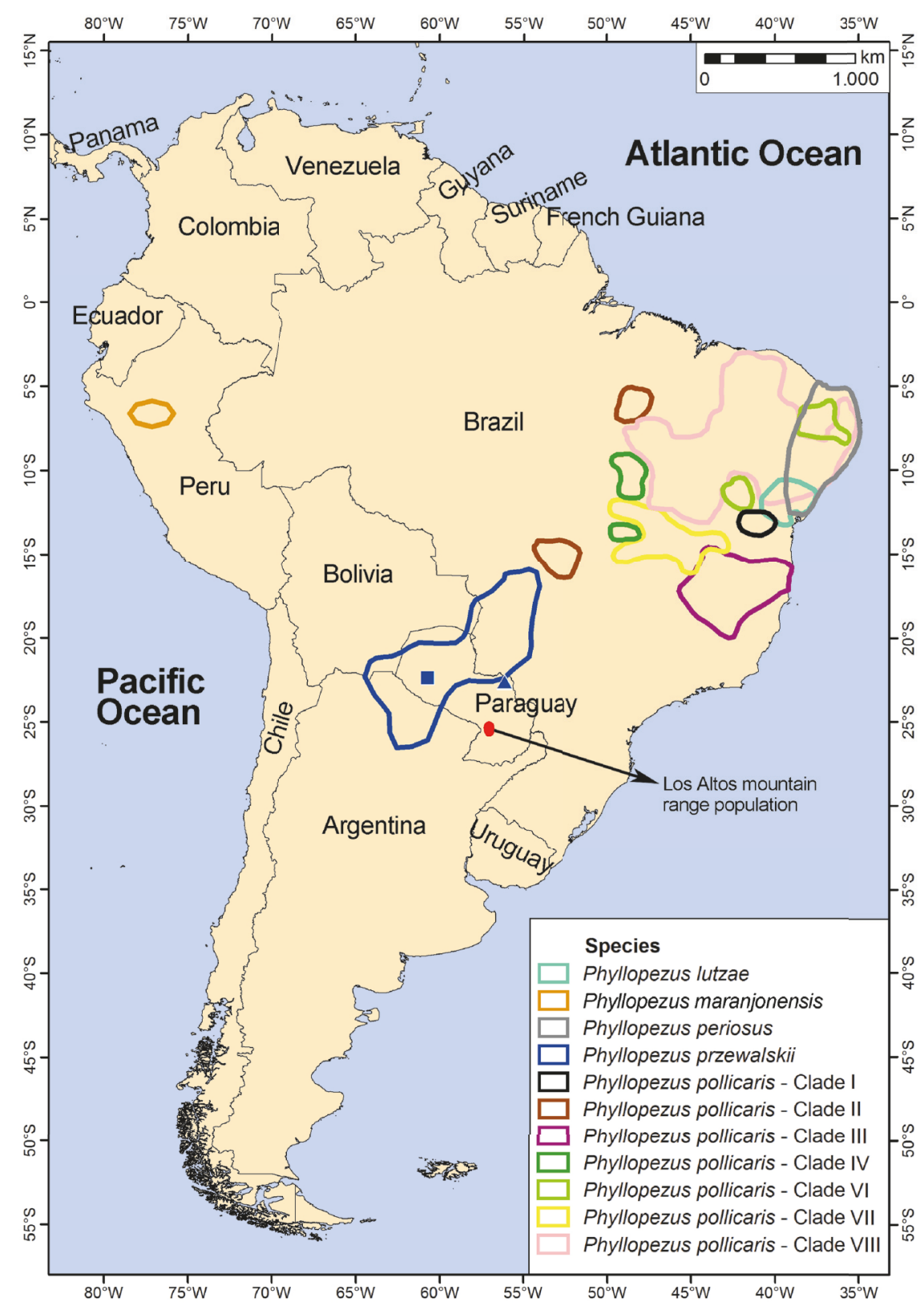

Figure 1: Distribution of the genus Phyllopezus according to Koch et al. [23] and Werneck et al. [11] indicating collection localities of our specimens. Red oval: Tobatí (in Los Altos mountain range). Square: Estancia La Amistad. Triangle: Parque Nacional Cerro Corá.

Phyllopezus are among the largest geckos in South America and they have a pattern of black or brown spots on gray or also whitish background color with a high intraspecific variation. Based on genetic analyses of Phyllopezus specimens (referred to as $P$. pollicaris) from the Chaco, Cerrado, and Caatinga ecoregions, a previous study found a high degree of genetic diversity in Cerrado and Caatinga (northeastern populations) specimens [10], followed by another study that proposed species status for $P$. przewalskii and designated seven additional taxa (within $P$. pollicaris sensu lato) as candidate species, thus, recognizing eleven tentative specieslevel units within this genus [11].
The distribution of Phyllopezus pollicaris sensu lato and P. przewalskii includes the "Dry Diagonal" [11], Chaco, Cerrado, and Caatinga, as well as another biome recognized as "Seasonally Dry Tropical Forest" [24]. In the last phylogenetic study of the genus, three major genetic lineages of Phyllopezus pollicaris sensu lato were recognized [11]: a northeastern group from the Caatinga, a central clade from the Cerrado, and a southwestern group whose distribution matches that of the Chaco sensu lato (Dry Chaco + Humid Chaco) (Figure 1). In Paraguay P. przewalskii is known from the Chaco $[25,26]$, where the species is a common ground dweller but also inhabits human dwellings. Phyllopezus is also present in the 
Paraguayan Cerrado [25, 26], where it occurs in rocky hills. Furthermore, there is another isolated population inhabiting a rocky hill formation named "Cordillera de Los Altos" (Los Altos mountain range) in the Departments of Paraguarí [27] and Cordillera [26], with an environment completely different to that of the Paraguayan Chaco or Cerrado (details of environments presented in Appendix S1). Populations from "Cordillera de Los Altos" and Paraguayan Cerrado have not been included in previous genetic analyses.

In this work we first explored the genetic distinctiveness of Phyllopezus specimens from the "Cordillera de Los Altos" and the Paraguayan Cerrado within the framework of a project about barcoding of Paraguayan herpetofauna using the mitochondrial 16S rRNA gene. Genetic data indicates that Phyllopezus from "Cordillera de Los Altos" constitute a genetic lineage differentiated from the remaining Paraguayan populations. Next, we incorporated additional mitochondrial genes (Cytb and ND2) to our analyses in order to assess phylogenetic relationships of Phyllopezus from "Cordillera de Los Altos" with previously published congeneric data (cluster arrangement according to Werneck et al. [11]).

\section{Materials and Methods}

We sampled Phyllopezus from three localities of Paraguay (Figure 1) and sequenced fragments of the mitochondrial 16S rRNA gene (GenBank accession numbers provided in Appendix S2) for comparison with sequences produced by Gamble et al. [10]. DNA was extracted from muscle stored in ethanol $98 \%$ at $-27^{\circ} \mathrm{C}$ using the standard glass fiber plate protocol of Ivanova et al. [28]. Samples were washed for about $14 \mathrm{~h}$ in $50 \mu \mathrm{l}$ of diluted PBS buffer (1:9 of buffer and water, respectively). Tissues were digested with vertebrate lysis buffer (60 $\mu \mathrm{l}$ per sample) and proteinase K (6 $\mu \mathrm{l}$ per sample) at $56^{\circ} \mathrm{C}$ for around $14 \mathrm{~h}$. After extraction, DNA samples were eluted in $50 \mu \mathrm{L}$ TE buffer. Amplification via double-stranded PCR of mitochondrial 16S rRNA fragments was performed using the Eurofins MWG Operon primers 16sar-L (forward: 5'-CGCCTGTTTATCAAAAACAT-3', also referred to as $\mathrm{L} 2510$ ) and $16 \mathrm{sbr}-\mathrm{H}$ (reverse: 5'CCGGTCTGAACTCAGATCACGT-3', also referred to as H3056) [29], in an Eppendorf Mastercycler ${ }^{\circledR}$ pro. The PCR conditions were as follows: initial denaturation $2 \min \left(94^{\circ} \mathrm{C}\right)$, denaturation $35 \sec \left(94^{\circ} \mathrm{C}\right) \times 40$, hybridization $35 \mathrm{sec}\left(48.5^{\circ} \mathrm{C}\right)$, elongation $60 \sec \left(72^{\circ} \mathrm{C}\right)$, and final elongation $10 \min \left(72^{\circ} \mathrm{C}\right)$. Cycle-sequencing and sequencing (BigDye Terminator) were performed with the same forward and reverse primers mentioned above. Partial sequences of mtDNA from cytochrome b (Cytb) and NADH dehydrogenase subunit 2 (ND2) genes were amplified according to the procedures presented in Werneck et al. [11]. Inspection of DNA chromatograms and generation of consensus sequences were performed with SeqTrace 0.9.0 [30].

Sequences were aligned using MAFFT $7[31,32]$ through the webserver (available at http://mafft.cbrc.jp/alignment/ server/). We included the Q-INS-i search strategy for the secondary structure of 16S [33]. Results of alignment were visualized and exported with MSA Viewer [34]. According to the respective requirements of the different software applications, the formats of the sequences were converted using the online server Alter [35]. The best substitution model for each gene (analyzed separately) of our dataset was identified using PartitionFinder2 [36], with linked branch lengths (supported by most of the phylogenetic programs) via PhyML 3.0 analysis [37]. Model selection was detected using the corrected (for finite sample size) Akaike Information Criterion (AICc) [38]. Given the correlation between gamma $(+\mathrm{G})$ and invariant sites $(+\mathrm{I})$ parameters, models that include both $+\mathrm{G}$ and $+\mathrm{I}$ are often inadequate [39-41]. Thus, we did not use models that included both parameters together. In all analyses, we used the Phyllodactylus unctus mitogenome (GenBank HQ896027) as an outgroup [42].

All of the following analyses were conducted for each gene individually, and the three genes concatenated. Sequences were concatenated in Mega 7.0.26 [43]. We performed Bayesian Inference analysis (BI) with MrBayes 3.2 [44, 45]. BI analyses were performed setting 5 runs with 8 chains discarding the first $25 \%$ as the burn-in period and an initial set of $1,000,000$ generations for MCMC with a sampling frequency of 500 generations, adding 500,000 generations until chains reached convergence. We considered convergence when the standard deviation of split frequencies was 0.015 or less. Additionally, convergence was diagnosed by PRSF (Potential Scale Reduction Factor) which should approach 1.0 as runs converge [46].

We used the IQTree webserver [47] to run a Maximum Likelihood (ML) analysis using 10,000 ultrafast Bootstrap approximation (UFBoot) replicates with 10,000 maximum iterations and minimum correlation coefficient of 0.99 [48] plus 10,000 replicates of Shimodaira-Hasegawa approximate likelihood ratio (SH-aLRT), which proved to be accurate with a high statistical power [37]. We used FigTree 1.3.1 for tree viewing (http://tree.bio.ed.ac.uk/software/figtree/).

We estimated evolutionary genetic divergence for the $16 \mathrm{~S}$ gene among sequences, computing uncorrected pairwise distances with Mega 7.0.26 to assess the degree of intraand interspecific differences, using a Bootstrap estimation method of 10,000 replications. Data were compared with those available from Gamble et al. [10].

To assess the phylogenetic position of the "Cordillera de Los Altos" clade within Phyllopezus, we designed a species tree based on the three mtDNA gene sequences concatenated, using *BEAST [49] in BEAST 2.4.7 [50] under 1,000,000 generations for the $\mathrm{mcmc}$ model, visualizing the posterior probability in DensiTree 2.2.6 [51].

We performed an initial species delimitation analysis by visualizing barcode gaps in the pairwise distribution of each mtDNA gene separately (excluding the outgroup), using the automatic barcode gap discovery (ABGD) approach [52] through its webserver (http://wwwabi.snv.jussieu.fr/public/ abgd/abgdweb.html), setting the use of Simple Distance, default values for Prior Intraspecific divergence, except for relative gap width (1.5) which does not work for some genes (as also noted by Kekkonen et al. [53]). Because high values in relative gap width tend to overly split species [54], we also used an intermediate value of 0.7 .

In addition to the molecular genetics, we measured the following morphological characters: snout-vent length (SVL) 
from the tip of the snout to the anterior edge of the cloaca; head length (HL) from the tip of the snout to the anterior edge of the ear opening; head width (HW) measured at the widest section of the head; nares-eye distance (NED) taken from the posterior border of the nares to the anterior edge of the eye; eye diameter (ED) measured at the widest section of the eye; maximum diameter of the ear opening (EO) taken at the widest point of the opening; minimum distance between nares (DBN) measured from above; and tail diameter (TD) taken at the base of the organ just posterior to the cloaca. Measurements were taken with digital calipers except SVL, which was taken with a meter stick. Meristic characters included the number of supralabials (SL) from the first scale behind the rostral scale to the last in contact with the mouth border; upper supralabial row (USL) from the first in contact with posterior nasal and first SL to the last scale before SL contact suboculars, infralabials (IL) from the first scale contacting the mental to the last in contact with the mouth border, and scales between $4^{\text {th }}$ and $5^{\text {th }}$ digital pads from the first lateral scale of the $5^{\text {th }}$ toe (the distalmost lateral finger scale that is not situated on the raised portion of the terminal phalanx) to the first lateral scale of the $4^{\text {th }}$ toe (Figure S1). When variation in the bilateral symmetry of morphological characters is present, a slash mark separates the respective values for left/right side. Measurements were always taken by the same person (PC). In the color descriptions, the capitalized colors and the color codes (in parentheses) are those of Köhler [55]. Specimens used for morphological comparison are listed in the Appendix.

We also explored the value of diagnostic characters traditionally used to differentiate between Phyllopezus pollicaris and $P$. przewalskii [20], which are postcloacal tubercles at the sides of the vent; number of lamellae under the fourth toe; and number of longitudinal rows of ventral scales (counted transversally at midbody). To do this, we compared samples from Paraguayan Chaco and Cerrado (which belong to $P$. przewalskii) with topotypes of $P$. pollicaris. Institutional acronyms follow Sabaj Pérez [56].

The Secretaría del Ambiente in Paraguay authorized euthanizing and collecting specimens, through the permits SEAM N $^{\circ}$ 04/11, SEAM N ${ }^{\circ}$ 009/2014, and SEAM N ${ }^{\circ}$ 133/2015.

\section{Results}

The final alignments of 16S, Cytb, and ND2 were of 498, 907, and 886 nucleotide positions, respectively, for 64 Phyllopezus samples plus Phyllodactylus unctus as an outgroup (Appendix S2). Partition schemes were recorded as follows: $16 \mathrm{~S}(\mathrm{GTR}+\mathrm{G})$; Cytb $\left(1^{\text {st }}\right.$ pos HKY $+\mathrm{I} \mid 2^{\text {nd }}$ pos K81UF+I $\mid 3^{\text {rd }}$ pos GTR+I); ND2 (GTR+I | HKY+G | TIM+I).

The trees obtained through BI and ML showed a high degree of concordance at well-supported nodes, with some differences in branch arrangement at poorly supported nodes (Figures S2-S7). The clade from "Cordillera de Los Altos" always clustered as the sister taxon of $P$. przewalskii (Figures S2-S7). Based on the concatenated genes, $P$. maranjonensis was the sister taxon to the remaining Phyllopezus taxa, followed by $P$. lutzae, and $P$. periosus as the sister clade to the remaining species within the genus. The Bayesian analysis (Figures 2, S8) generally showed higher support values than ML (Figure S9). The branches corresponding to $P$. pollicaris Clade I and $P$. pollicaris Clade II are clustered together. An important polyphyly is observed in $P$. pollicaris Clade III which appears as the sister clade to $P$. pollicaris Clade IV + $P$. przewalskii, and one sample is located as the sister group to the cluster $P$. pollicaris Clade VI $+P$. pollicaris Clade VII + P. pollicaris Clade VIII (Figure 2). Both hypotheses (BI and ML) suggest a branch with the southwestern taxa (Los Altos population + P. przewalskii + Phyllopezus pollicaris Clade IV) differentiated from the remaining $P$. pollicaris clades. The $P$. przewalskii clade shows specimens from the Cerrado and from the Chaco separately; and specimens from "Cordillera de Los Altos" mountain range are recovered as a sister clade to $P$. przewalskii. The final alignment and trees (along with methods and parameters) are stored in TreeBASE (ID N ${ }^{\circ}$ 22091) available at https://treebase.org/ treebase-web/home.html.

The highest intraclade pairwise distance reaches $6.65 \%$ in Phyllopezus pollicaris Clade VII and $4.4 \%$ in P. przewalskii (Appendix S3). The minimum pairwise distance between two clades usually is higher than $10 \%$ with the exception of the minimum distances between $P$. pollicaris Clade IV and $P$. przewalskii (9.9\%), as well as between $P$. pollicaris Clade VIII with $P$. przewalskii (10.4\%), P. pollicaris Clade VI (8.2\%), and Clade VII (7.1\%), respectively (Appendix S3).

Samples from Los Altos mountain range present high values for pairwise genetic distance, reaching a genetic distance of $16.8 \%$ with $P$. periosus (Appendix S3). The smallest genetic distance of the Los Altos mountain range population is $11.8 \%$ with $P$. pollicaris Clade IV (Appendix S3). Genetic distances between the Los Altos population and its sister clade, $P$. przewalskii, is $12.6-14.4 \%$.

The species tree shows $P$. periosus, $P$. maranjonensis and $P$. lutzae clustered together and sister to the remaining Phyllopezus (Figure 3). The highest support is observed in the clusters $P$. pollicaris Clade I + P. pollicaris Clade II, P. pollicaris Clade VI + P. pollicaris Clade VII $+P$. pollicaris Clade VIII, and P. przewalskii + Phyllopezus sp. (Figure 3).

Results from ABGD suggest the presence of a higher diversity within Phyllopezus than currently recognized (Figure 4). The gene 16S seems to be the most conservative recognizing 11 different species (Clades II and III not included given the lack of samples), while ND2 recognized 15 species, and 18 species were recognized by Cytb (Figure 4). Full results of ABGD are found in Appendix S4. The mitochondrial Cytb gene suggests a higher diversity especially in Clade VII. This gene, as well as ND2, distinguishes the sample MTR 13452 ( $P$. pollicaris Clade III) as a species separated from the remaining Clade III. Finally, the three genes are concordant in the recognition of the samples from "Cordillera de Los Altos" as a different taxon (Figure 4, Appendix S4).

\section{Taxonomic Implications}

The specimens from "Cordillera de Los Altos" mountain range exhibit a high genetic differentiation from all other studied populations of Phyllopezus. Moreover, the specimens 


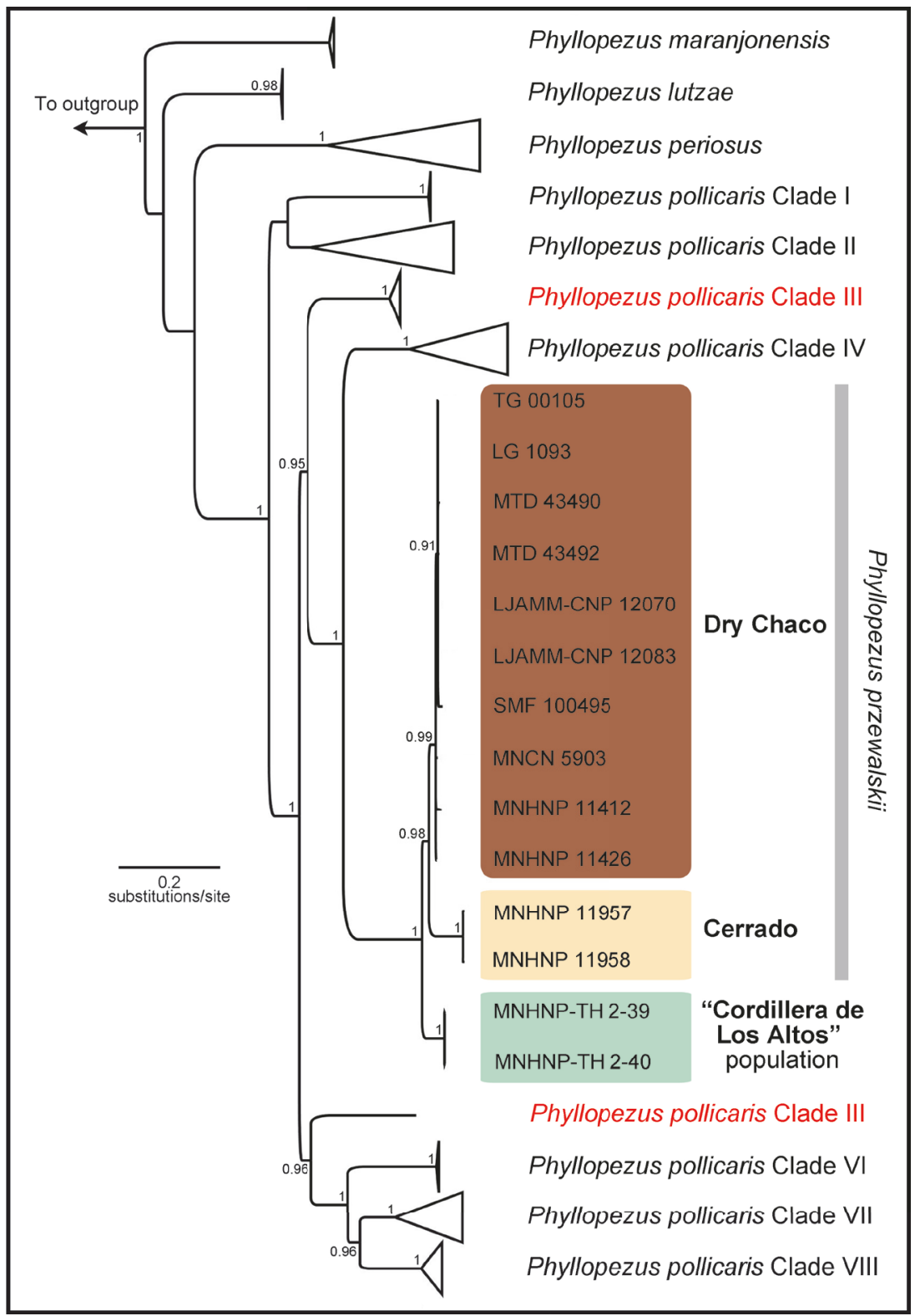

Figure 2: Bayesian tree obtained from concatenated mitochondrial genes (16S, Cytb, and ND2) of the gecko genus Phyllopezus. Numbered clades of $P$. pollicaris represent the groups recognized by Werneck et al. [11]. Most of clades (with the exception of $P$. przewalskii) are collapsed. For details on specimens' allocation see Figure S8. In red, there is a clade that appears to be polyphyletic. Samples from Dry Chaco are shown in a brown box, those from Cerrado are shown in a yellow box, and in a green box are specimens from "Cordillera de los Altos." Only PP values higher than 0.9 are shown. Outgroup: Phyllodactylus unctus.

from "Cordillera de Los Altos" are recovered as a clade phylogenetically distinct from the other clades. Finally, the population from "Cordillera de Los Altos" can be differentiated from the other species of this genus by subtle characters of coloration and scalation. Therefore, applying the general lineage species concept [57], we recognize the Phyllopezus population from the "Cordillera de Los Altos" as a separate species, described below.

This published work and the nomenclatural acts it contains have been registered in Zoobank: urn:lsid:zoobank.org: act:9E9B8965-B517-49A0-84D9-F7BC57A85E33, and therefore they are available under the International Code of
Zoological Nomenclature. The Life Science Identifier (LSID) for this publication is as follows: urn:lsid:zoobank.org:pub: 1AE503A1-8CE0-460F-B29C-90B722DF905D. The LSID registration and any associated information can be viewed in a web browser by adding the LSID to the prefix "http://zoobank .org/."

\section{Phyllopezus heuteri sp. nov.}

Holotype. SMF 100494 (original field number GK 3559), adult female (Figure 5), collected on 12 September 2016 by G. Köhler, at the Cerro de Tobatí $\left(25.2797^{\circ} \mathrm{S}, 57.0925^{\circ} \mathrm{W}\right.$, 


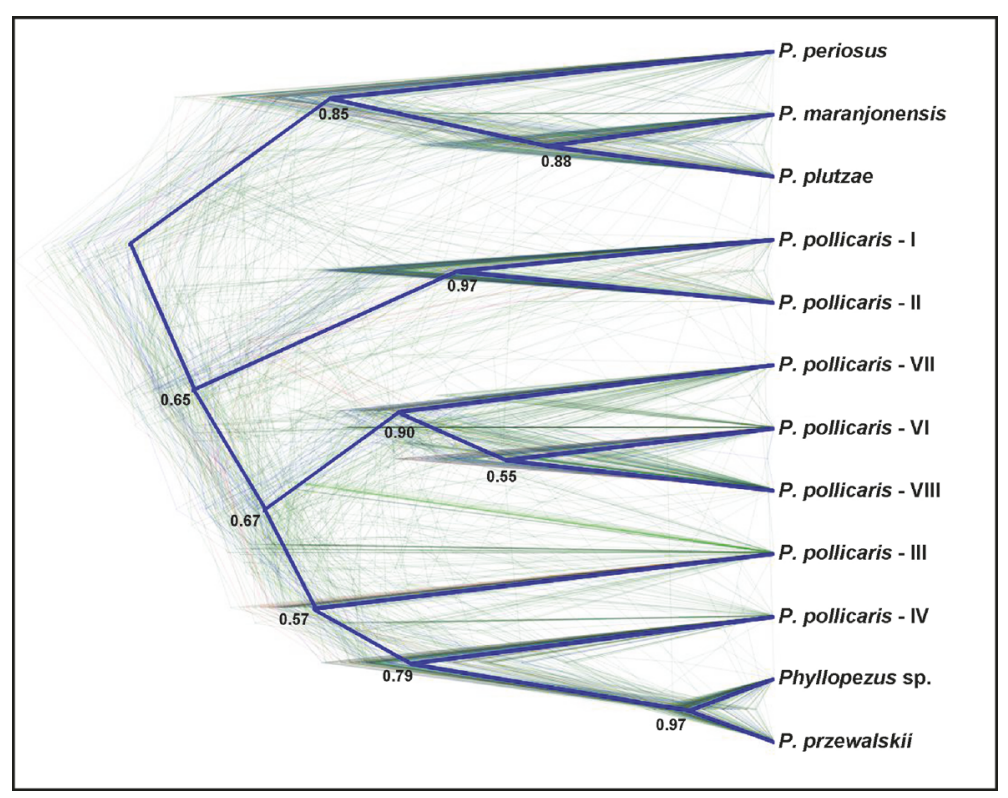

FIGURE 3: Species tree inferred with $*$ BEAST showing density of trees proportional to frequency of occurrence (thin lines) drawn in DensiTree and the consensus tree (blue lines) with the posterior probability for each node.

428 masl), in the Cordillera de Los Altos mountain range, Cordillera Department, Paraguay (Figure 6).

Paratypes. MVZ 110967 (unidentified sex), collected on 7 October 1972 by Phil Myers, at $1 \mathrm{mi}$ S of Tobatí, Cordillera, Paraguay; UNNEC 1005 (unidentified sex), collected on 3 March 1998 by M. Culzzoni and B. Álvarez, at Chololó $\left(25.55138^{\circ} \mathrm{S}, 57.0400^{\circ}\right.$ W, 272 masl), Paraguarí, Paraguay; MNHNP 11975 (adult male), collected on November 2014 by J. Méndez, at Cerro de Tobatí, Cordillera, Paraguay; MNHNP 12001 (adult male), collected on 23 April 2013 by J. Méndez, at Cerro de Tobatí, Cordillera, Paraguay; MNHNP 12111 (adult female) and MNHNP 12112 (adult male), collected on 27 January 2012 by J. Méndez, S. Escobar and T. López, at Cerro Hũ (25.6069 S, 57.1294 W, 365 masl), Paraguarí, Paraguay; SMF 100696 (adult female) collected on 16 April 2016 by P. Cacciali, F. Bauer and J. Méndez, at Cerro de Tobatí (25.2854 S, 57.0934 W, 157 masl), Cordillera, Paraguay.

Diagnosis. A medium-sized species of Phyllopezus with a color pattern consisting of irregular transversal bands or reticulations of dark colors on a grayish background, and large tubercles irregularly disposed on the body. Morphologically $P$. heuteri can be differentiated from $P$. lutzae by the irregular reticulated or banded coloration (versus dotted pattern in $P$. lutzae) and by the presence of tubercles on the body (versus absent) (Figure S10). Phyllopezus heuteri is distinguished from $P$. maranjonensis by the smaller size (max. SVL $88 \mathrm{~mm}$ versus $115 \mathrm{~mm}$ in P. maranjonensis) and presence of tubercles on the lateral surfaces of the body as well as between eyes and ear opening (versus absent from these regions) (Figure S11) and spiny scales surrounding the ear opening (versus cycloids) (Figure S12). Phyllopezus heuteri is differentiated from $P$. periosus by irregularly shaped elements of color pattern (versus well defined transversal bands in $P$. periosus), by spiny scales surrounding the ear opening (versus cycloid scales) (Figure S12), and by the contact between the two greatly enlarged postmentals (versus enlarged lateral postmentals separated by small median postmentals) (Figure S13). Phyllopezus heuteri is distinguished from $P$. pollicaris by the presence of two to three larger scales (tubercle-shaped) at the mouth commissure (versus small homogeneous scales at the mouth commissure in P. pollicaris), lateral body tubercles reaching further downwards (lowermost tubercle at 6-8 lateral scales from ventrals versus 13-15), and presence of more tubercles (five to eight) between eye and ear opening (versus up to three) (Figure S14). Phyllopezus heuteri can be distinguished from $P$. przewalskii by the presence of tubercles on the prescapular region and sides of the neck (versus homogeneous scalation in $P$. przewalskii) (Figure S15), the presence of 36 to 39 scales between $4^{\text {th }}$ and $5^{\text {th }}$ toes (versus 33 to 36 ), and its large postmentals usually contacting only the first IL (versus contacting usually $1^{\text {st }}$ and $2^{\text {nd }} \mathrm{IL}$ ).

Description of the Holotype. SVL $74 \mathrm{~mm}$, tail incomplete, HL $19.1 \mathrm{~mm}$, HW 14.1, NED $6.9 \mathrm{~mm}$, ED $4.6 \mathrm{~mm}$, EO $1.6 \mathrm{~mm}$, DBN $2.4 \mathrm{~mm}$, and TD $7.5 \mathrm{~mm}$; rostral wide, with a median groove at the upper side of the scale; nares surrounded by rostral, nasorostral, supranasal, postnasal, and first SL; SL: 10/11; USL: 15/13; upper surface of the muzzle with a shallow median depression; lateral and upper surfaces of the head covered with granular juxtaposed scales, with scattered tubercles on the upper surface starting at the level of the posterior edge of the eye; supraocular scales spine-shaped posterior to the level of the center of the eye; IL: 9/10; mental bell-shaped with the narrower part posteriorly; two greatly enlarged postmentals contacting each other, the mental, the first IL, and a small portion of the second IL; postmentals 


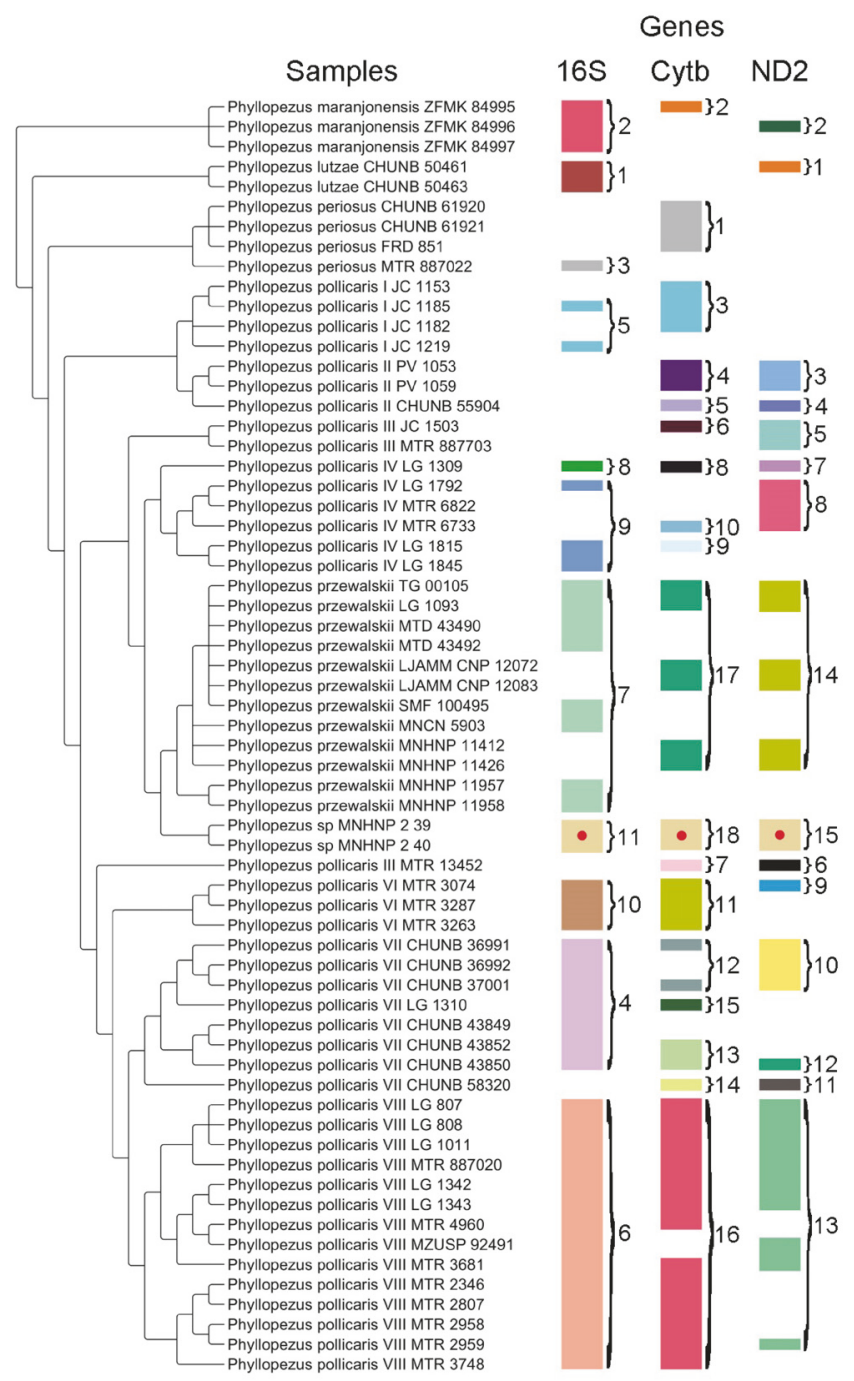

FIGURE 4: Results of ABGD analysis for each gene. Colors represent groups identified by ABGD for each gene, with group numbers presented at the right. As seen, not all samples were available for all genes. Group colors do not represent the same grouping among genes, except for samples from "Cordillera de Los Altos" which are identified with a cream colored box with a red central dot. Base phylogeny (at the left) is the same as for Figure 2.

followed by a row of five smaller scales; scales under the head gradually reducing in size posteriorly; dorsal and lateral parts of the neck covered with granular juxtaposed scales with irregular rows of tubercles; throat region with juxtaposed and cycloid homogeneous scales; dorsum of the body with granular scales and tubercles approximately 2.5 times the size of the surrounding granular scales, disposed in 8 or 9 irregular rows on each side reaching onto flanks; ventral scales cycloid and imbricate, arranged in 32 longitudinal rows at midbody; limbs covered with granular juxtaposed scales, except on the dorsal surface of the upper arms and thighs that present slightly imbricated scales; forelimbs more slender than hind limbs; infradigital lamellae of hands starting from pollex were recorded as follows: 5/6 - 10/9 10/11 - 10/10 - 9/8; infradigital lamellae of feet starting from hallux were recorded as follow: 6/5 - 10/9 - 11/11 - 10/12 - 8/9; claws enclosed by a sheath of six rows of scales; a single slightly developed postcloacal tubercle on each side; tail with imbricate, cycloid scales that are smaller on the dorsal and larger on the lateral surfaces, and an enlarged median subcaudal row of scales covering most of the ventral surface.

Coloration in Life. (Figure 7) dorsal ground color of body Pale Neutral Gray (296), with irregular transversal bands grading from Brownish Olive (292) into Raw Umber (280), bordered posteriorly by Cream White (52) and interrupted by a Beige (254) vertebral stripe. Lateral surfaces of the body Pale Neutral Gray (296) with scattered Raw Umber (280) speckling. Venter Cream White (52). Dorsal and lateral surfaces of the head Smoke Gray (267) with Cream White (52) and Raw Umber (280) speckles more concentrated on the occipital area. Ventral surface of the head Cream White (52) with Hair Brown (227) stipples concentrated in the infralabial 

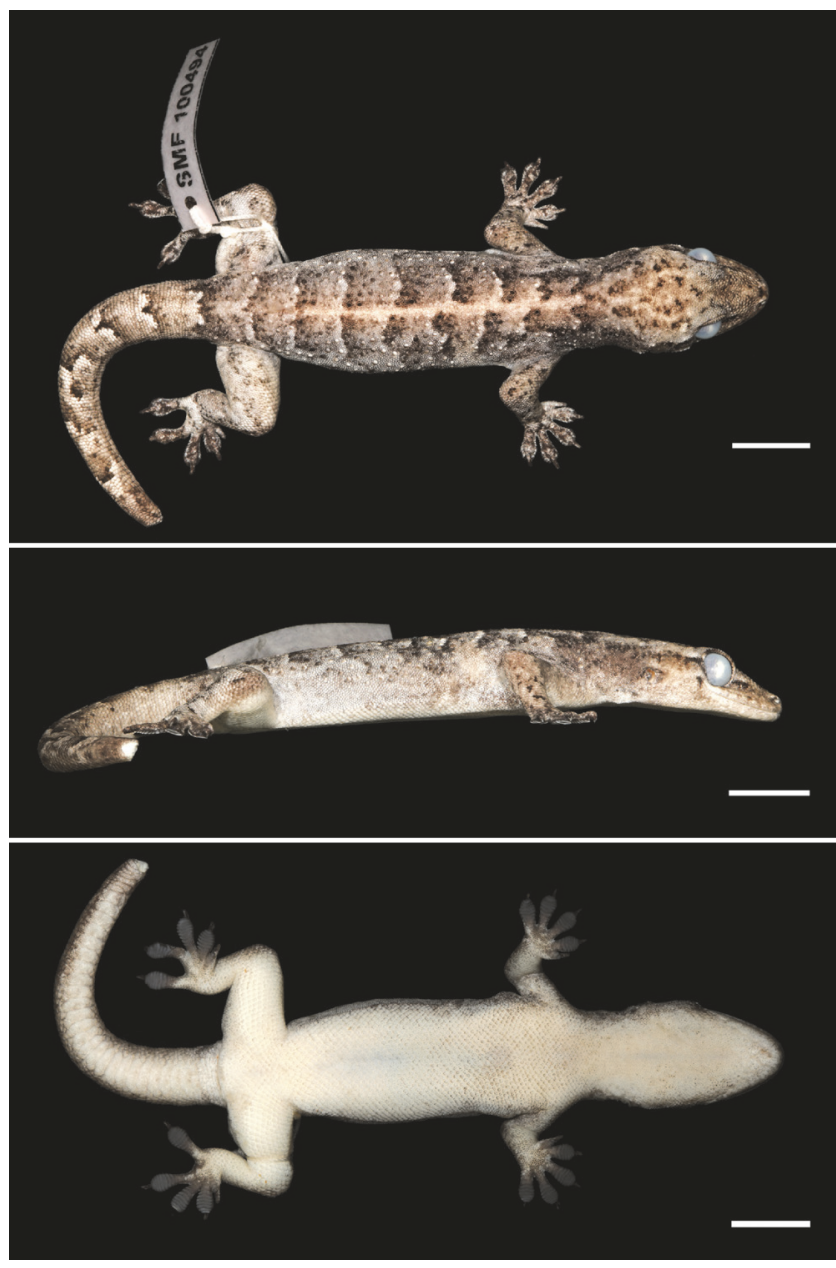

FIGURE 5: Dorsal (above), lateral (middle), and ventral (below) views of the holotype (SMF 100494) of Phyllopezus heuteri. Scale bars $=10$ $\mathrm{mm}$.

area. Limbs Pale Neutral Gray (296) with reticula of Raw Umber (280) dorsally, and immaculate Cream White (52) ventrally. Ground color of the tail (only original portion of the tail described) Pale Gray (262) with irregular dorsal (transverse) bands reaching onto flanks that are Light Drab (269) grading into Raw Umber (280) posteriorly followed by Smoky White (261) halo. Ventral surface of the tail Pale Horn Color (11).

Coloration in Preservative. (After five years in ethanol 70\%) dorsal ground color Medium Neutral Gray (298), with irregular transversal bands Vandyke Brown (282), posteriorly bordered by Lavender (202); interrupted by a Pale Mauve (204) vertebral stripe. Lateral surfaces of the body Medium Neutral Gray (298) with scattered Dusky Brown (285) speckles. Venter Smoky White (261). Dorsal and lateral surfaces of the head Smoke Gray (267) with Pale Buff (1) and Raw Umber (280) speckles. Ventral surface of the head Smoky White (261) with Fawn Color (258) stipples concentrated in the infralabials. Limbs Light Neutral Gray (297) with reticulum of Brownish Olive (292) on the dorsal side of arms and Jet Black (300) on legs, and immaculate Smoky White (261) on the ventral surface. Ground color of the tail (only original portion of the tail described) Pale Gray (262) with irregular dorsal (transverse) diffused Smoke Gray (266) bands reaching onto flanks grading into Vandyke Brown (282) posteriorly followed by Smoky White (261) halo. Ventral surface of the tail Smoky White (261) with lateral suffusions of Smoke Gray (207).

Variation among the Paratypes. SVL ranging from 60 to 73 $\mathrm{mm}$ in males and 77 to $88 \mathrm{~mm}$ in females (mean SVL 72.8 $\mathrm{mm}$ for both sexes combined); None of the tails of our examined specimens is complete and original (being either regenerated or broken and incomplete); HL 16.5-21.8 mm (25.6-27.5\% of SVL in males and $24.4-25.8 \%$ in females); HW $12.2-18.6 \mathrm{~mm}$ (0.65-0.82 proportion HW/HL in males and 0.73-0.85 in females); NED 6.1-8.3 mm; ED 3.8-5.0 mm (0.60-0.64 proportion ED/NED in males, and $0.59-0.66$ in females); EO 1.6-2.0 mm (9.5-10.9\% of HL in males and 8.2-10.6 \% in females); DBN 2.0-2.8 mm (14.5-18.8\% of $\mathrm{HW}$ in males and 14.2-17.0\% in females); TD 7.2-8.5 mm (11.6-12.0\% of SVL) in males, and 7.8-10.6 mm (10.1-12.0\% of SVL) in females; rostral scale always of a similar shape, but the median groove can extend more than half of the scale downwards; SL 9 or 10; USL from 10 to 15; IL 8 or 9; postmentals contacting only the first IL in all specimens except the holotype; one specimen (MNHNP 12001) with three large postmentals; 27 to 33 longitudinal rows of ventral scales at midbody; infradigital lamellar variation for hands and feet is presented in Table 1; postcloacal tubercles vary from two to three per side.

The most remarkable aspects of variation in color pattern are visible on the dorsum. The largest examined specimen (MNHNP 12111) has no pattern other than the vertebral stripe present in all specimens. The remaining specimens show a pattern composed of bands similar to that of the holotype, but the bands are formed by a mottling in MNHNP 11975, and two specimens exhibit only very diffuse bands. One specimen (MNHNP 12001) has a paler ground color, and another (SMF 100696) exhibits a darker ground color.

Distribution. Phyllopezus heuteri is known from rocky outcrops at three localities along the "Cordillera de Los Altos" formation (Figure 6) in the Paraguayan departments Cordillera and Paraguarí, at 268-428 m above sea level.

Natural History. Given the scarcity of records this gecko is not well known. It appears to be a nocturnal species found on sandstone rocky hills. It seeks shelter in caves or cracks in the rocks. Its coloration is mimetic with the lichens and mosses that cover the rocks' surfaces. The area where Phyllopezus heuteri is present has a marked seasonality regarding rainfall and temperature (dry and cold season from May to September) with an annual precipitation of about 1200 to $1300 \mathrm{~mm}$. The vegetation associated with the rocky environment is composed of thorny or thick plants such as Polycarpaea hassleriana, Cereus sp., and Bromelia sp. Nothing is known about its feeding or reproductive habits, or any other aspects of its behavior. 
TABle 1: Morphological variation among Phyllopezus heuteri, P. pollicaris, and P. przewalskii.

\begin{tabular}{lccccccccccc}
\hline & \multicolumn{3}{c}{ Hands } & \multicolumn{9}{c}{ Feet } & \multicolumn{3}{c}{ V } \\
& 1 & 2 & 3 & 4 & 5 & 1 & 2 & 3 & 4 & $10-11$ & $28-30$ \\
\hline Ppol & $6-7$ & $10-12$ & 11 & $9-11$ & $9-10$ & $6-7$ & $10-11$ & $11-12$ & $9-12$ & 12 \\
Pprz & $5-6$ & $8-9$ & $9-11$ & $9-11$ & $8-9$ & $5-6$ & $8-10$ & $10-12$ & $10-11$ & $8-10$ & $24-33$ \\
Pheu & $3-6$ & $7-10$ & $9-11$ & $9-11$ & $7-9$ & $5-6$ & $9-10$ & $10-12$ & $9-11$ & $8-9$ & $27-33$ \\
\hline
\end{tabular}

Infradigital lamellar variation (including holotype) of Phyllopezus heuteri (Pheu) and the most closely related species, P. pollicaris (Ppol) and P. przewalskii (Pprz). Variation is presented from the pollex (1) to the $5^{\text {th }}$ finger of the hands and from the hallux (1) to the $5^{\text {th }}$ toe of the feet. Also presented is the range of longitudinal rows of ventral scales (Vent).

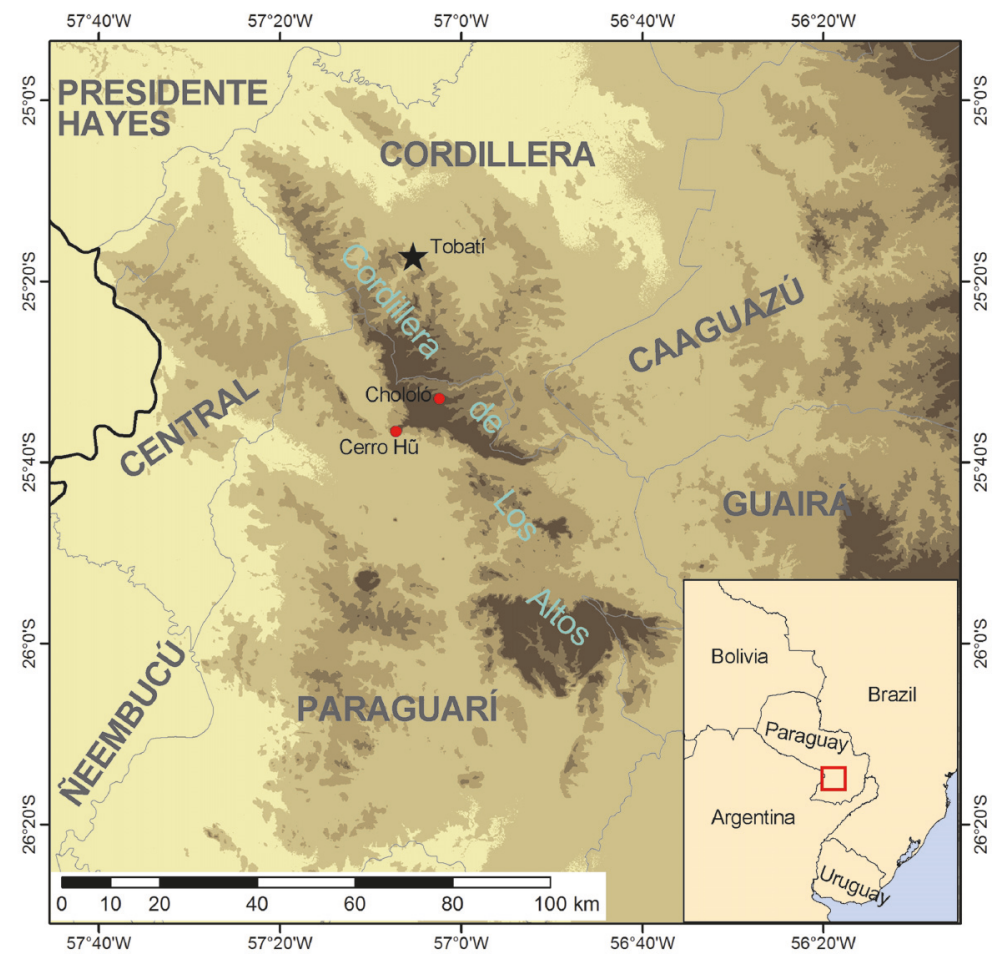

Figure 6: Known records of Phyllopezus heuteri showing the type locality (black star) and additional localities (red dots). Capitalized names refer to Paraguayan Departments.

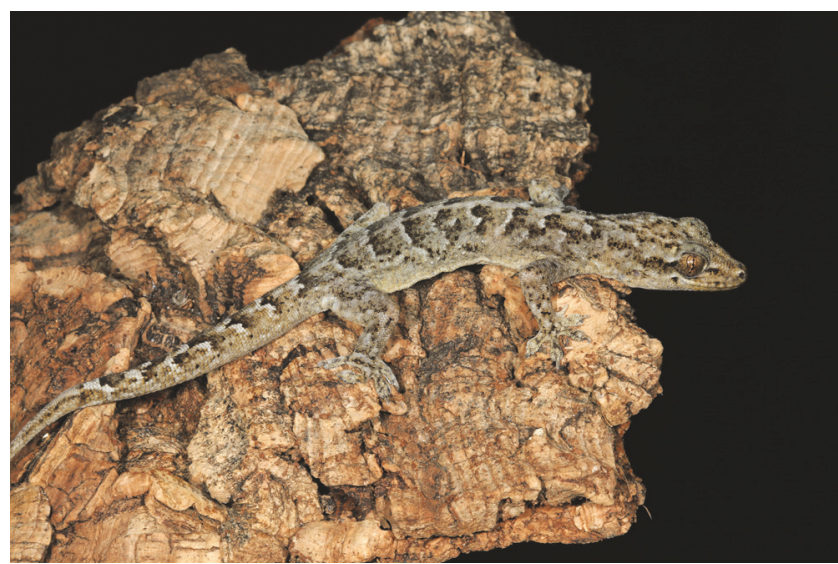

Figure 7: Coloration in life of the holotype (SMF 100949) of Phyllopezus heuteri.
Etymology. The specific name is a patronym for biologist Dr. Horst Heuter from Berlin, Germany, in recognition of the financial support of taxonomic research provided by Dr. Heuter through the BIOPAT initiative.

\section{Discussion}

The fact that Phyllopezus przewalskii was long considered as a subspecies of $P$. pollicaris can be attributed to the large overlaps in all proposed diagnostic characters: number of lamellae under the fourth toe ( 9 to 13 in $P$. pollicaris, and 8 to 11 in $P$. przewalskii), ventral scales at midbody (28 to 32 in $P$. pollicaris, and 26 to 29 in $P$. przewalskii), and postcloacal tubercles at the sides of the vent (always present in $P$. pollicaris, not always present in adults of $P$. przewalskii) $[20,21]$. According to Werneck et al. [11] none of the $P$. 


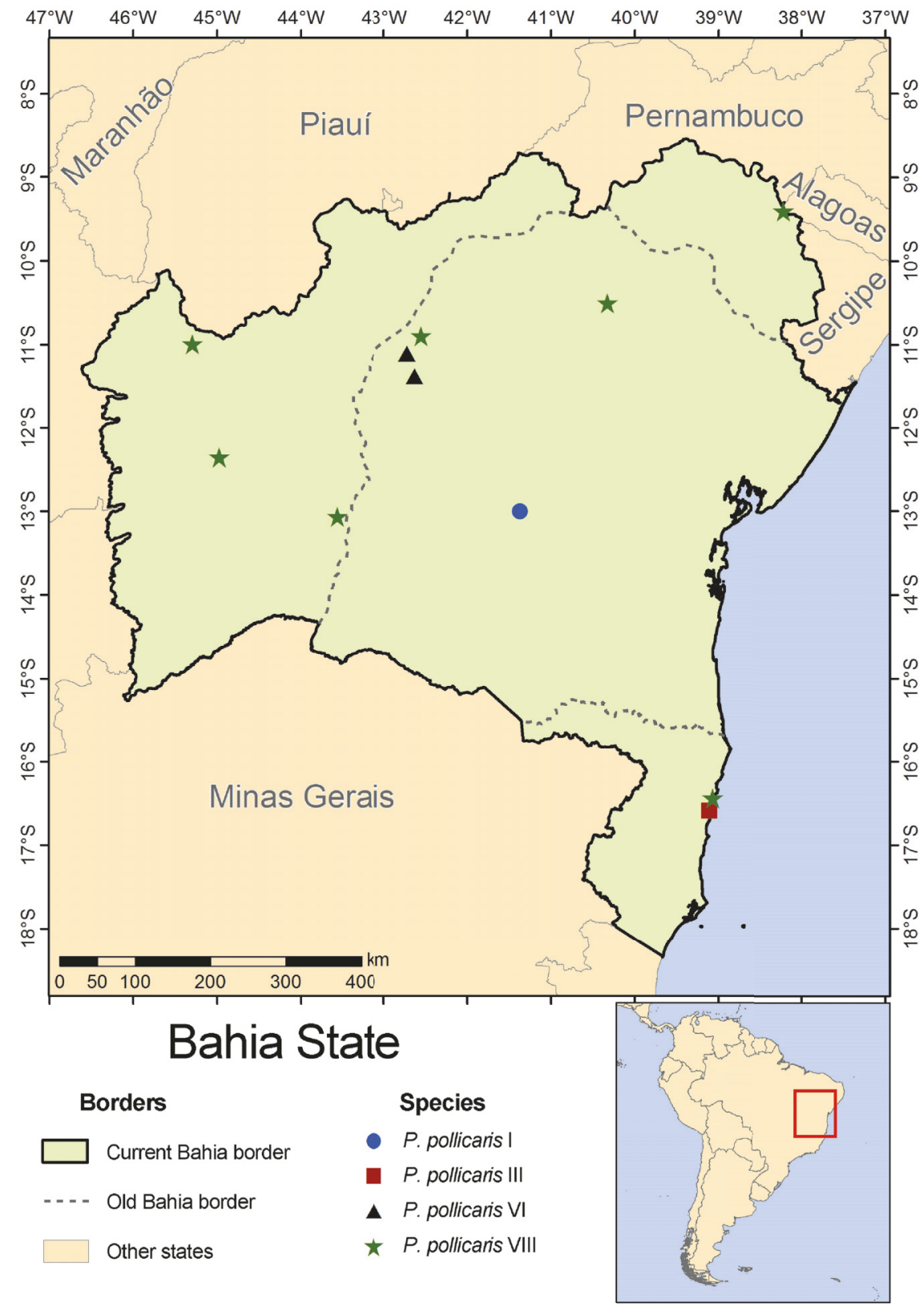

Figure 8: Candidate species present in the Brazilian State of Bahia (type locality for P. pollicaris), considering current and old borders.

pollicaris clades reaches Paraguay where only P. przewalskii is present, but the "diagnostic" characters of Paraguayan specimens show a variation beyond those established for either P. pollicaris or P. przewalskii (Table 1). Werneck et al. [11] provided evidence that the genus Phyllopezus is composed of multiple cryptic lineages, several of which are not formally described as species yet and therefore were not included in our morphological comparisons. The name $P$. pollicaris cannot confidently be assigned to any of the Werneck et al. [11] clades because the type locality Thecadactylus pollicaris ("sylvis interioris Bahiae campestribus") (Spix 1825: 17 [58]) is not precise enough. According to the distribution map of the Phyllopezus clades of Werneck et al. ([11]: last page of Supporting Information file) four candidate species are present in the Brazilian State of Bahia: Phyllopezus pollicaris clades I, III, VI, and VIII. Even though Bahia was much smaller at the time when the type specimen was collected, still three clades remain as possible candidates for the true P. pollicaris (Figure 8).

To avoid confusion and get as closely as possible to the "real" $P$. pollicaris sensu stricto, our characterization of $P$. pollicaris is based on two paralectotypes that according to Müller and Brongersma [59] were part of the original type series that the description of Spix (1825 [58]) is based on and 
came from the same locality as the lectotype (ZSM 2510/0, considered lost, Michael Franzen comm. pers.). Nevertheless, paralectotypes have no legal status as name-bearing types, and therefore this issue remains to be solved.

Similarly, the taxonomic status of Phyllopezus goyazensis (Peters 1878) also needs to be accounted for. The P. goyazensis type locality of is stated as "Goyaz" in Brazil [60], which, at the time, was larger than the current boundaries of the modern Goiás state and included what is now Goiás and Tocantins. Three of the putative species from Werneck et al. [11] occur in this area, clades IV, VII, and VIII. Fortunately, the P. goyazensis type is still extant (ZMB 9079), which should make assigning that name easier than the aforementioned $P$. pollicaris problem.

Morphological differences are slight among the closest relative species of Phyllopezus (P. pollicaris, P. przewalskii, and $P$. heuteri), rendering it a genus with remarkable morphological crypsis. Nevertheless, Phyllopezus heuteri is relatively easily distinguishable from the phylogenetically most distant species: P. lutzae, P. maranjonensis, and P. periosus, showing more resemblance with $P$. pollicaris and $P$. przewalskii. We found high variation in traditional diagnostic characters for P. przewalskii (Table 1) which overlap with those proposed for $P$. pollicaris [20,21]. Nevertheless, we found some characters in head and body scalation, which allow distinguishing $P$. heuteri and P. przewalskii, respectively, from P. pollicaris sensu stricto. Phyllopezus heuteri and P. przewalskii are morphologically similar, but there are differences in the number of scales between $4^{\text {th }}$ and $5^{\text {th }}$ toes and in the shape of scales on the sides of the neck as well as in the prescapular region (Figure S11). Additionally, P. przewalskii seems to have the cephalic tubercles more developed but we found some intraspecific variation in that character. With respect to coloration, like many other geckos, $P$. heuter $i$ is capable of metachrosis, which can cause it to mimic different substrates (Figure 9).

Phyllopezus heuteri shows a high degree of genetic differentiation according to $p$-distances, having the lowest distance to its sister clade P. przewalskii (Appendix S3). Phyllopezus pollicaris Clade VII and P. pollicaris Clade VIII have the smallest distances (7.77-10.53\%) among all pairs of clades. Werneck et al. [11] found higher genetic distances even at the intraspecific level with values that reach $27.5 \%$ between haploclades of $P$. pollicaris Clade VIII and genetic distances of 16.9 to $24.6 \%$ between $P$. pollicaris Clade VII and $P$. pollicaris Clade VIII.

\section{Conclusions}

For almost a century, the genus Phyllopezus was considered as monotypic with two subspecies, until two more species were described and more recent works revealed an even higher species-level diversity [10,11]. We add to this growing knowledge with the description of a new species from a poorly sampled area at the southern margin of the distributional range of the genus. We highlight the importance of a morphological analysis that can put practicable names on the candidate species recognized by genetic data. Phyllopezus heuteri is a rock dweller as many other members of the genus,

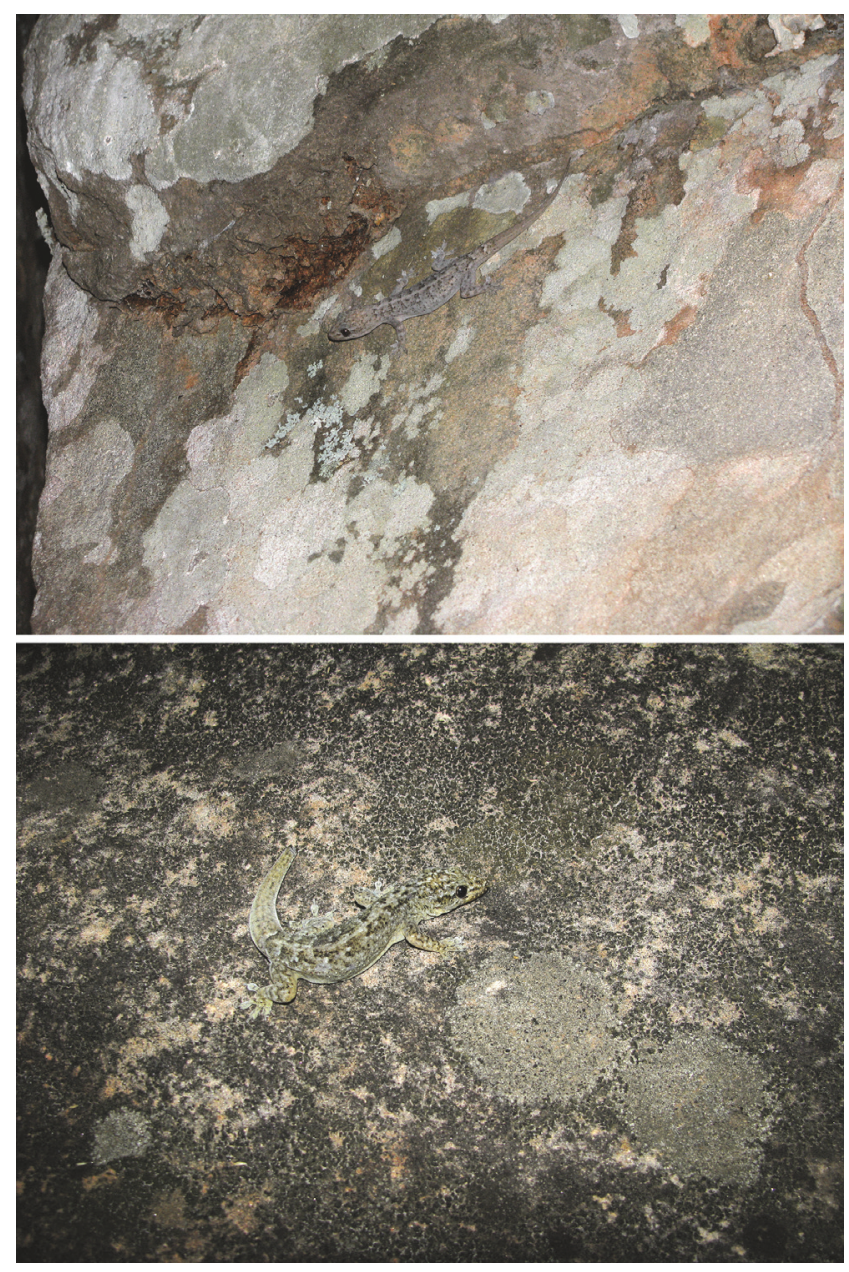

FIGURE 9: Differences in coloration of $P$. heuteri between animals on light green lichens and pinkish rock substrates (above) and animals on rocks fully covered by dark green lichens (below).

and the split between this species and P. przewalskii (its closest relative) occurred before the latter species colonized the xerophytic Chaco. This paper represents another contribution oriented to resolving the taxonomy of the genus Phyllopezus, and we hope that the unnamed clades can be morphologically diagnosed in further studies.

\section{Appendix}

\section{Examined Specimens}

Phyllopezus lutzae (3). Brazil: Bahia: São Salvador (AMNH 65381, MCZ 46190 [Syntype], UMMZ 115644 [Syntype]).

Phyllopezus maranjonensis (3). Peru: Amazonas: Quebrada Honda (ZFMK 84995-7 [Paratypes]).

Phyllopezus periosus (3). Brazil: Paraíba: Cabeceiras (AMNH 131825, MCZ 172929-30). 
Phyllopezus pollicaris (2). Brazil: Bahia (no more specific locality data) (ZSM 165/0/1-2 [Paralectotypes]).

Phyllopezus przewalskii (59). Argentina: Chaco: Fuerte Esperanza (LJAMM-CNP 12094-5). Formosa: Ingeniero Juárez (LJAMM-CNP 12071, 12084; MACN 3230). Santiago del Estero: Pampa de los Guanacos (MACN 4999). Bolivia: Santa Cruz: San Antonio de Parapeti (MACN 47006-7, 47009-10). Tarija: Villamontes (SMF 29259-64).

Paraguay: (No additional data) MNHNP 11174, 11176. Alto Paraguay: Bahía Negra (MNHNP 10202, 11691); Colonia Potrerito (MNHNP 3371); Parque Nacional Defensores del Chaco (MNHNP 2850, 4298); Puerto Ramos (MNHNP 3243-6, 3248-9). Amambay: Parque Nacional Cerro Corá (MNHNP 6983, 7046, 7640-4, 11919). Boquerón: Establecimiento Ko'e Pyahu (MNHNP 11069); Estancia Agropil S.A. (MNHNP 8042); Estancia Amistad (SMF 100495-6); Estancia Jabalí (MNHNP 8043-4, 8071); Estancia Mbutú Retã (MNHNP 3818); Filadelfia (MNHNP 2851); Parque Nacional Teniente Enciso (MNHNP 2853, 3253, 4300, 11797, 11847, 11857). Concepción: Vallemí (MACN 12860-6).

\section{Data Availability}

Sequences used for this study are stored in GenBank. See Appendix for specifications. Sequence matrices and trees are deposited in TreeBASE ID N 22091.

\section{Conflicts of Interest}

The authors declare that they have no conflicts of interest.

\section{Acknowledgments}

The authors' thanks go to F. Bauer, N. Martínez, J. Méndez, M. Ruiz Díaz, E. Buongermini, and D. Vázquez for help during field work; also to M. Motte (MNHNP), L. Avila (LJAMMCNP), J. Faivovich (MACN), B. Álvarez (UNNEC), C. Spencer (MVZ), D. Rödder (ZFMK), F. Glaw (ZSM), R. Nussbaum (UMMZ), and D. Kizirian (AMNH) for letting them analyze specimens under their care; to C. Pérez (LJAMMCNP), A. Marín (LJAMM-CNP), S. Nenda (MACN), S. Palomas (UNNEC), C. Koch (ZFMK), M. Franzer (ZSM), G. Schneider (UMMZ), L. Mogk (SMF), C. Zimmer (SMF), and E. Buongermini (Subtropica, Paraguay), for help and assistance during specimens' revision; and to $\mathrm{H}$. Kappes (Grunelius-Möllgaard Labor, SMF) and B. J. Pinto (MU) for assistance with laboratory work. The Consejo Nacional de Ciencia y Tecnología (CONACYT) from Paraguay, through the "Programa Nacional de Incentivo a los Investigadores" (PRONII) program, funded Pier Cacciali for fieldwork. Also, AMERISUR Paraguay provided financial support for revision of scientific collections. Pier Cacciali also is grateful to "Iki" (S. Saldivar) and "Chori" (V. Martínez) for delivering fieldwork equipment supplied by Idea Wild. Also thanks are due to N. C. Haase for the revision of an early draft of the manuscript. This paper arose six years ago from an early idea, strongly encouraged by A. Yanosky (Asociación Guyra
Paraguay, Paraguay), so Pier Cacciali gives him a special acknowledgment. This work is part of an ongoing project of Barcoding of Paraguayan Herpetofauna, as part of the Ph.D. work of Pier Cacciali, funded by the Deutscher Akademischer Austauschdienst (DAAD, Germany).

\section{Supplementary Materials}

Appendix S1: environmental traits of Phyllopezus habitats in Paraguay. Appendix S2: GenBank accession numbers of sequences used in this work. Appendix S3: pairwise genetic distances (16S). Appendix S4: results of the ABGD assessment. Figure S1: scales between $4^{\text {th }}$ and $5^{\text {th }}$ digital pads. Figure S2: phylogenetic tree inferred from 16S using BI approach. Figure S3: phylogenetic tree inferred from 16S using ML approach. Figure S4: phylogenetic tree inferred from Cytb using BI approach. Figure S5: phylogenetic tree inferred from Cytb using ML approach. Figure S6: phylogenetic tree inferred from ND2 using BI approach. Figure S7: phylogenetic tree inferred from ND2 using ML approach. Figure S8: phylogenetic tree inferred from concatenated genes, using BI approach. Figure S9: phylogenetic tree inferred from concatenated genes, using ML approach. Figure S10: dorsal scalation. Figure S11: head and lateral body scalation. Figure S12: ear opening. Figure S13: mental scalation. Figure S14: lateral scalation of the head. Figure S15: prescapular scalation. (Supplementary Materials)

\section{References}

[1] P. E. Vanzolini and A. M. M. Ramos, "A new species of Colobodactylus, with notes on the distribution of a group of stranded microteiid lizards (Sauria, Teiidae)," Papéis Avulsos de Zoologia, vol. 31, pp. 19-47, 1977.

[2] E. H. Bucher, "Chaco and Caatinga - South American Arid Savannas, Woodlands and Thickets," in Ecology of Tropical Savannas, B. J. Huntley and B. H. Walker, Eds., vol. 42, pp. 4879, Springer-Verlag, Heidelberg, Berlin, Germany, 1982.

[3] M. A. Mares, M. R. Willig, and T. E. Lacher, "The Brazilian Caatinga in South American Zoogeography: Tropical Mammals in a Dry Region," Journal of Biogeography, vol. 12, no. 1, pp. 5769, 1985.

[4] D. E. Prado and P. E. Gibbs, "Patterns of Species Distributions in the Dry Seasonal Forests of South America," Annals of the Missouri Botanical Garden, vol. 80, no. 4, pp. 902-927, 1993.

[5] F. Mayle, “The Late Quaternary Biogeographical History of South American Seasonally Dry Tropical Forests: Insights from Palaeo-Ecological Data," in Neotropical Savannas and Seasonally Dry Forests: Plant Diversity, Biogeography, and Conservation, R. T. Pennington, G. P. Lewis, and J. A. Ratter, Eds., pp. 395-416, CRC Press, Boca Raton, Florida, 2006.

[6] E. E. Gutiérrez, R. P. Anderson, R. S. Voss, J. Ochoa-G., M. Aguilera, and S. A. Jansa, "Phylogeography of Marmosa robinsoni: insights into the biogeography of dry forests in northern South America," Journal of Mammalogy, vol. 95, no. 6, pp. 11751188, 2014.

[7] D. M. Neves, K. G. Dexter, R. T. Pennington, M. L. Bueno, and A. T. Oliveira Filho, "Environmental and historical controls of floristic composition across the South American Dry Diagonal," Journal of Biogeography, vol. 42, no. 8, pp. 1566-1576, 2015. 
[8] F. P. Werneck, "Biogeografia Molecular e Reconstruções Espaço-temporais Aplicadas aos Estudo da Diversificação da Biota da Diagonal de Formações Abertas e Zonas de Transição," in Biogeografia da América do Sul: Análise de Tempo, Espaço e Forma, C. J. B. de Carvalho and E. A. B. Almeida, Eds., pp. 141156, Roca, Rio de Janeiro, 2nd edition, 2016.

[9] C. E. Guarnizo, F. P. Werneck, L. G. Giugliano et al., "Cryptic lineages and diversification of an endemic anole lizard (Squamata, Dactyloidae) of the Cerrado hotspot," Molecular Phylogenetics and Evolution, vol. 94, pp. 279-289, 2016.

[10] T. Gamble, G. R. Colli, M. T. Rodrigues, F. P. Werneck, and A. M. Simons, "Phylogeny and cryptic diversity in geckos (Phyllopezus; Phyllodactylidae; Gekkota) from South America's open biomes," Molecular Phylogenetics and Evolution, vol. 62, no. 3, pp. 943-953, 2012.

[11] F. P. Werneck, T. Gamble, G. R. Colli, M. T. Rodrigues, and J. Sites, "Deep diversification and long-term persistence in the South American "Dry Diagonal": integrating continent-wide phylogeography and distribution modeling of geckos," Evolution, vol. 66, no. 10, pp. 3014-3034, 2012.

[12] S. R. Palumbi and F. Cipriano, "Species identification using genetic tools: The value of nuclear and mitochondrial gene sequences in whale conservation," Journal of Heredity, vol. 89, no. 5, pp. 459-464, 1998.

[13] J. A. Rudnick, T. E. Katzner, E. A. Bragin, and J. A. DeWoody, "Species identification of birds through genetic analysis of naturally shed feathers," Molecular Ecology Resources, vol. 7, no. 5, pp. 757-762, 2007.

[14] L. Yang, Z. Tan, D. Wang et al., "Species identification through mitochondrial rRNA genetic analysis," Scientific Reports, vol. 4, no. 1, article no. 4089, 2015.

[15] J. Sites and J. C. Marshall, "Delimiting species: a renaissance issue in systematic biology," Trends in Ecology and Evolution, vol. 18, no. 9, pp. 462-470, 2003.

[16] J. H. Pinzón and T. C. Lajeunesse, "Species delimitation of common reef corals in the genus Pocilloporausing nucleotide sequence phylogenies, population genetics and symbiosis ecology," Molecular Ecology, vol. 20, no. 2, pp. 311-325, 2011.

[17] S. Khodami, P. Martinez Arbizu, S. Stöhr, and S. Laakmann, "Molecular Species Delimitation of Icelandic Brittle Stars (Ophiuroidea)," Polish Polar Research, vol. 35, no. 2, pp. 243260, 2014.

[18] F. Leliaert, H. Verbruggen, P. Vanormelingen et al., "DNA-based species delimitation in algae," European Journal of Phycology, vol. 49, no. 2, pp. 179-196, 2014.

[19] L. G. Giugliano, C. de Campos Nogueira, P. H. Valdujo, R. G. Collevatti, and G. R. Colli, "Cryptic diversity in South American Teiinae (Squamata, Teiidae) lizards," Zoologica Scripta, vol. 42, no. 5, pp. 473-487, 2013.

[20] P. E. Vanzolini, "Sobre o gênero Phyllopezus Peters (Sauria, Gekkonidae)," Papéis Avulsos de Zoologia, vol. 11, pp. 353-369, 1953.

[21] J. A. Peters and R. Donoso-Barros, "Catalogue of the Neotropical Squamata, Part. II; lizards and amphisbaenians," Bulletin of the United States National Museum, no. 297, pp. 1-293, 1970.

[22] M. T. Rodrigues, "Uma nova espece do gênero Phyllopezus de Cabaceiras: Paraiba: Brasil; com comentarios sobre a fauna de lagartos da area (Sauria Gekkonidae)," Papéis Avulsos de Zoologia, vol. 36, pp. 237-250, 1986.

[23] C. Koch, P. J. Venegas, and W. Böhme, "A remarkable discovery: description of a big-growing new gecko (Squamata:
Gekkonidae: Phyllopezus) from northwestern Peru," Salamandra, vol. 42, no. 2/3, pp. 145-150, 2006.

[24] D. E. Prado, "Seasonally dry forests of tropical South America: From forgotten ecosystems to a new phytogeographic unit," Edinburgh Journal of Botany, vol. 57, no. 3, pp. 437-461, 2000.

[25] A. L. Aquino, N. Scott, and M. Motte, "Lista de los anfibios y reptiles del Museo Nacional de Historia Natural del Paraguay," in Colecciones de Fauna y Flora del Museo Nacional de Historia Natural del Paraguay, O. Romero Martínez, Ed., pp. 331-400, Ministerio de Agricultura y Ganadería, Asunción, Paraguay, 1996.

[26] P. Cacciali, N. Scott, A. L. Aquino, L. A. Fitzgerald, and P. Smith, "The Reptiles of Paraguay: literature, distribution, and an annotated taxonomic checklist," Special Publications of the Museum of Southwestern Biology, vol. 11, pp. 1-373, 2016.

[27] M. Culzzoni and B. B. Alvarez, "Phyllopezus pollicaris przewalskyi (Brazilian Gecko)," Geographic distribution. Herpetological Review, vol. 27, p. 211, 1996.

[28] N. V. Ivanova, J. R. Dewaard, and P. D. N. Hebert, "An inexpensive, automation-friendly protocol for recovering high-quality DNA," Molecular Ecology Notes, vol. 6, no. 4, pp. 998-1002, 2006.

[29] S. Palumbi, A. Martin, S. Romano, WO. McMillan, L. Stice, and G. Grabowski, The simple fools guide to PCR, Version 2, Honolulu, University of Hawaii, 2002.

[30] B. J. Stucky, "SeqTrace: A Graphical Tool for Rapidly Processing DNA Sequencing Chromatograms," Journal of Biomolecular Techniques : JBT, vol. 23, no. 3, pp. 90-93, 2012.

[31] K. Katoh, K. Misawa, K. Kuma, and T. Miyata, "MAFFT: a novel method for rapid multiple sequence alignment based on fast Fourier transform," Nucleic Acids Research, vol. 30, no. 14, pp. 3059-3066, 2002.

[32] K. Katoh and D. M. Standley, "MAFFT multiple sequence alignment software version 7: improvements in performance and usability," Molecular Biology and Evolution, vol. 30, no. 4, pp. 772-780, 2013.

[33] K. Katoh and H. Toh, "Improved accuracy of multiple ncRNA alignment by incorporating structural information into a MAFFT-based framework," BMC Bioinformatics, vol. 9, article no. 212, 2008.

[34] G. Yachdav, S. Wilzbach, B. Rauscher et al., "MSAViewer: Interactive JavaScript visualization of multiple sequence alignments," Bioinformatics, vol. 32, no. 22, pp. 3501-3503, 2016.

[35] D. Glez-Peña, D. Gómez-Blanco, M. Reboiro-Jato, F. FdezRiverola, and D. Posada, "ALTER: program-oriented format conversion of DNA and protein alignments," Nucleic Acids Research, vol. 38, pp. 14-18, 2010.

[36] R. Lanfear, P. B. Frandsen, A. M. Wright, T. Senfeld, and B. Calcott, "PartitionFinder 2: new methods for selecting partitioned models of evolution formolecular and morphological phylogenetic analyses," Molecular Biology and Evolution, vol. 34, no. 3, pp. 772-773, 2016.

[37] S. Guindon, J. Dufayard, V. Lefort, M. Anisimova, W. Hordijk, and O. Gascuel, "New algorithms and methods to estimate maximum-likelihood phylogenies: assessing the performance of PhyML 3.0," Systematic Biology, vol. 59, no. 3, pp. 307-321, 2010.

[38] K. P. Burnham and D. R. Anderson, Model Selection and Multimodel Inference: A Practical Information-Theoretic Approach, Springer-Verlag, NY, USA, 2nd edition, 2002.

[39] J. Sullivan, D. L. Swofford, and G. J. P. Naylor, "The effect of taxon sampling on estimating rate heterogeneity parameters 
of maximum-likelihood models," Molecular Biology and Evolution, vol. 16, no. 10, pp. 1347-1356, 1999.

[40] I. Mayrose, N. Friedman, and T. Pupko, "A gamma mixture model better accounts for among site rate heterogeneity," Bioinformatics, vol. 21, no. 2, pp. ii151-iil58, 2005.

[41] Z. Yang, Computational Molecular Evolution. Oxford Series in Ecology and Evolution, 2006.

[42] J. Yan, C. Tian, L. Lv, A. M. Bauer, and K. Zhou, "Complete mitochondrial genome of the San Lucan gecko, Phyllodactylus unctus (Sauria, Gekkota, Phyllodactylidae), in comparison with Tarentola mauritanica," Mitochondrial DNA, vol. 25, no. 3, pp. 202-203, 2014.

[43] S. Kumar, G. Stecher, and K. Tamura, "MEGA7: Molecular Evolutionary Genetics Analysis version 7.0 for bigger datasets," Molecular Biology and Evolution, vol. 33, no. 7, pp. 1870-1874, 2016.

[44] J. P. Huelsenbeck and F. Ronquist, "MrBayes: Bayesian inference of phylogenetic trees," Bioinformatics, vol. 17, no. 8, pp. 754-755, 2001.

[45] F. Ronquist and J. P. Huelsenbeck, "MrBayes 3: bayesian phylogenetic inference under mixed models," Bioinformatics, vol. 19, no. 12, pp. 1572-1574, 2003.

[46] A. G. Gelman and D. B. Rubin, "Inference from iterative simulation using multiple sequences," Statistical Science, vol. 7, no. 4, pp. 457-472, 1992.

[47] J. Trifinopoulos, L.-T. Nguyen, A. von Haeseler, and B. Q. Minh, "W-IQ-TREE: a fast online phylogenetic tool for maximum likelihood analysis," Nucleic Acids Research, vol. 44, no. 1, pp. W232-W235, 2016.

[48] B. Q. Minh, M. A. T. Nguyen, and A. von Haeseler, "Ultrafast approximation for phylogenetic bootstrap," Molecular Biology and Evolution, vol. 30, no. 5, pp. 1188-1195, 2013.

[49] A. J. Drummond, M. A. Suchard, D. Xie, and A. Rambaut, "Bayesian phylogenetics with BEAUti and the BEAST 1.7," Molecular Biology and Evolution, vol. 29, no. 8, pp. 1969-1973, 2012.

[50] H. A. Ogilvie, R. R. Bouckaert, and A. J. Drummond, "StarBEAST2 brings faster species tree inference and accurate estimates of substitution rates," Molecular Biology and Evolution, vol. 34, no. 8, pp. 2101-2114, 2017.

[51] R. R. Bouckaert and J. Heled, "DensiTree 2: Seeing trees through the forest," BioRxiv, 2014.

[52] N. Puillandre, A. Lambert, S. Brouillet, and G. Achaz, "ABGD, Automatic Barcode Gap Discovery for primary species delimitation," Molecular Ecology, vol. 21, no. 8, pp. 1864-1877, 2012.

[53] M. Kekkonen, M. Mutanen, L. Kaila, M. Nieminen, and P. D. N. Hebert, "Delineating species with DNA barcodes: A case of Taxon dependent method performance in moths," PLoS ONE, vol. 10, no. 4, Article ID e0122481, 2015.

[54] Z. Yang, J.-F. Landry, and P. D. N. Hebert, "A DNA barcode library for North American Pyraustinae (Lepidoptera: Pyraloidea: Crambidae)," PLoS ONE, vol. 11, no. 10, Article ID e0161449, 2016.

[55] G. Köhler, Color Catalogue for Field Biologists, Herpeton, Offenbach, Germany, 2012.

[56] M. H. Sabaj Pérez, Standard symbolic codes for institutional resource collections in herpetology and ichthyology: an Online Reference. Version 5.0, American Society of Ichthyologists and Herpetologists, 2014, http://www.asih.org/, Accessed 10 Apr 2017.
[57] K. de Queiroz, The general lineage concept of species, species criteria, and the process of speciation, D. J. Howard and H. B. Stewart, Eds., Oxford University Press, 1998.

[58] J. B. Spix, "Animalia nova sive species nova lacertarum quas in itinere per Brasiliam annis MDCCCXVII-MDCCCXX jussu et auspiciis Maximiliani Josephi I Bavariae Regis suscepto collegit et descripsit Dr. J. B. de Spix. Monacco," 1825.

[59] L. Müller and L. D. Brongersma, "Ueber die Identität von Thecadactylus pollicaris Spix 1825 mit Phyllopezus goyazensis Peters 1877," Zoologische Mededelingen, vol. 15, pp. 156-161, 1933.

[60] W. Peters, "Herpetologische Notizen. II. Bemerkungen über neue oder weniger bekannte Amphibien," Monatsberichte der Königlich Preussischen Akademie der Wissenschaften zu Berlin, pp. $415-423,1878$. 


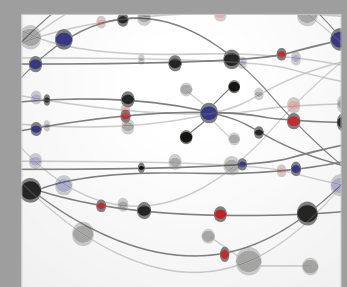

The Scientific World Journal
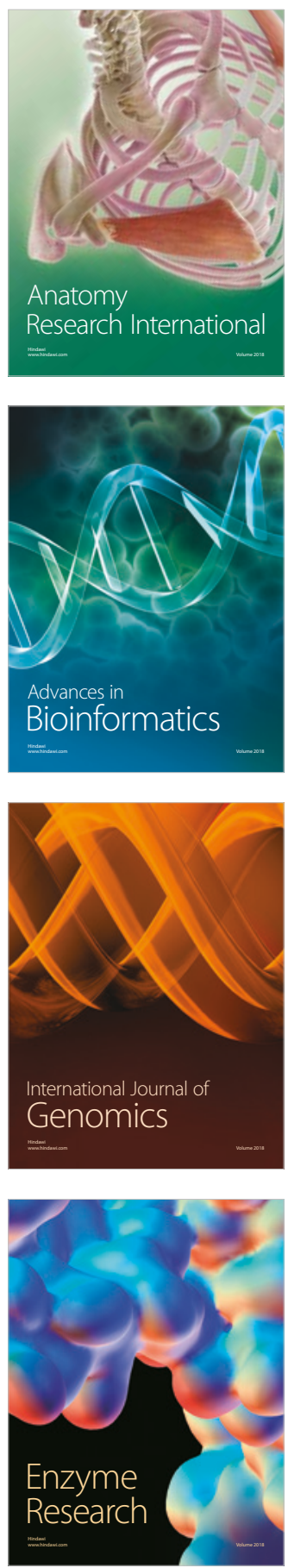
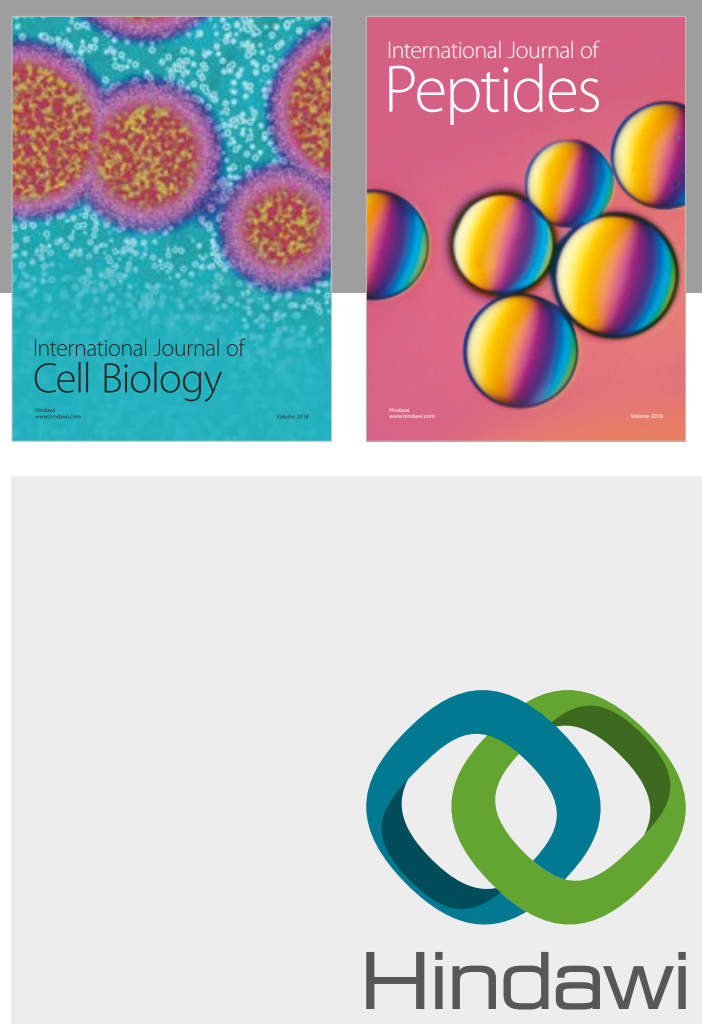

Submit your manuscripts at

www.hindawi.com
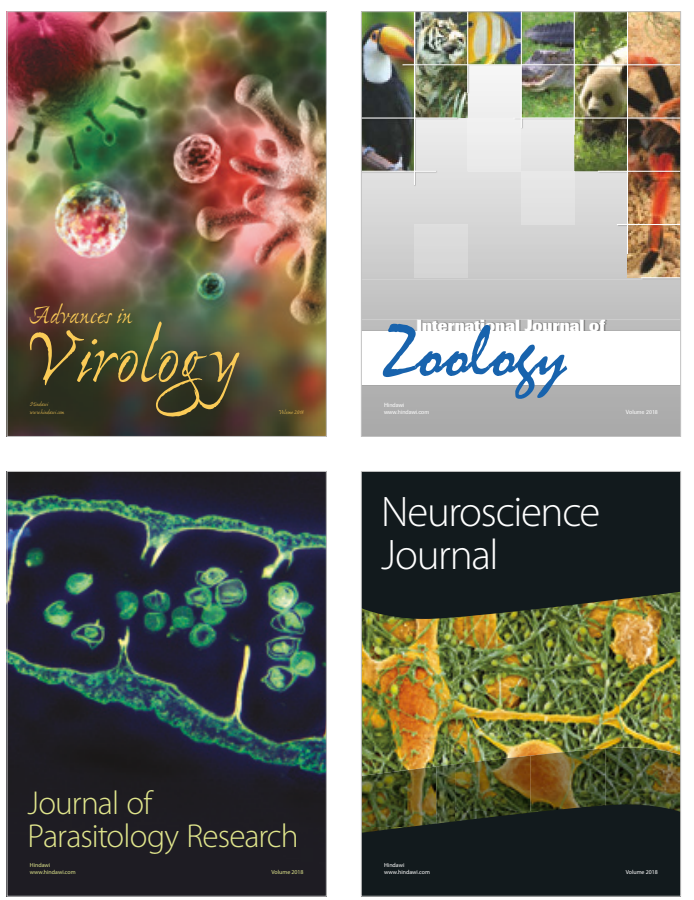
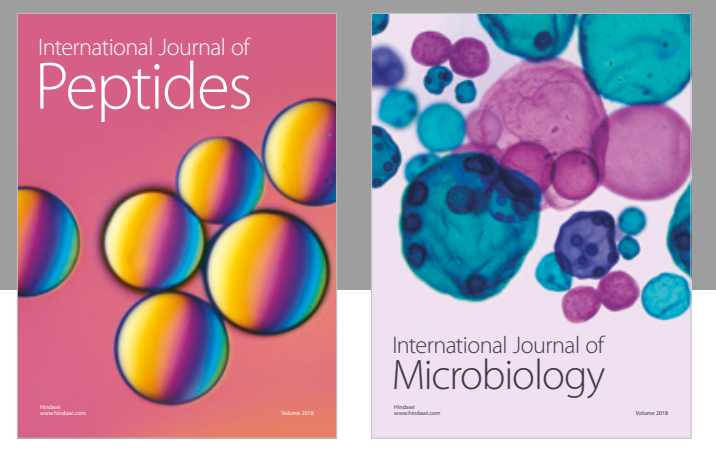

nternational Journal of Microbiology
Journal of
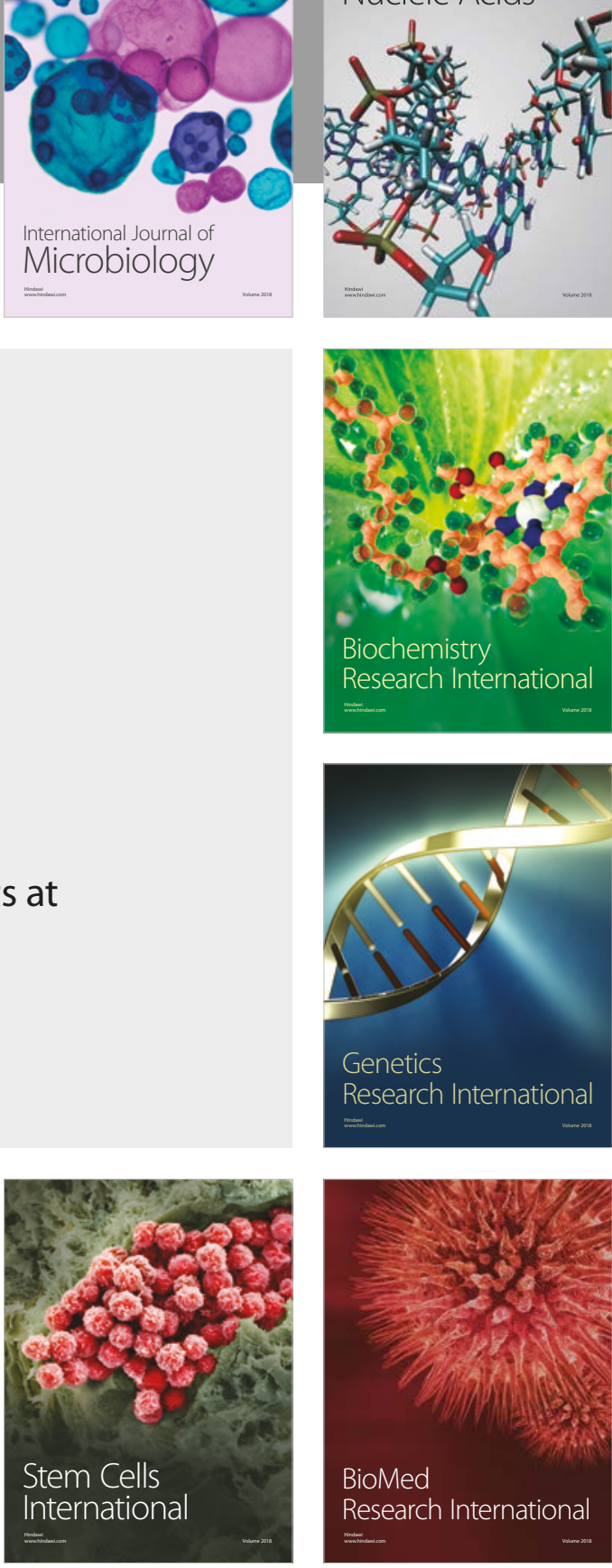
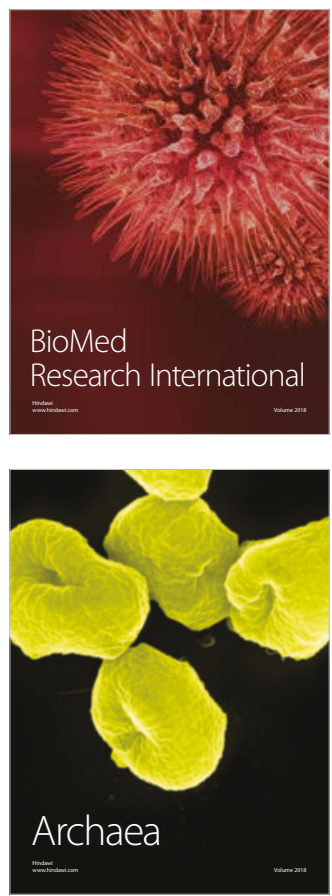